\title{
STRATEGIC ANALYSIS OF THE EXTERNAL AND INTERNAL ENVIRONMENT OF SPORT TOURISM AT THE “BANJA VRUĆICA” SPA
}

\author{
ZORAN MILINKOVIĆ ${ }^{1}$, SLOBODAN SIMOVIĆl, ADRIANA LJUBOJEVIĆ2 ${ }^{2}$ JELENA JOVANOVIĆ³, \\ KRISTINA PANTELIĆ BABIĆl \\ IUniversity of Banja Luka, Bosnia and Herzegovina, Faculty of Physical Education and Sport, \\ Department of Sport Management \\ 2University of Banja Luka, Bosnia and Herzegovina, Faculty of Physical Education and Sport, \\ Department of Sport Recreation \\ ${ }^{3}$ University of Belgrade, Serbia, Faculty of Sport and Physical Education, Department of Sport Management
}

Mailing address: Slobodan Simović, University of Banja Luka, Faculty of Physical Education and Sport, 1A Petra Bojovića Blvd, 78000 Banja Luka, Bosnia and Herzegovina, tel.: +387 65 580750, fax: +387 51 312280, e-mail: slobodan.simovic@ffvs.unibl.org

\begin{abstract}
Introduction. Numerous international and local organisations and agencies have in the past 15 years dealt with various issues and problems related to tourism in Bosnia and Herzegovina. Often, they have accentuated the large potential for tourism development and improvement, particularly when it comes to spa tourism. Although all elements necessary for development (tradition, accommodation capacities, natural resources, and traffic connections) are present, the "Banja Vrućica" spa is still unable to respond to modern tourism market demands so that it can contribute to the economic growth and development in the national and local economies. The successful running of a tourist destination requires the formulation of long-term goals and decisions, reached through a process of strategic management. The aim of this article is to use strategic analysis as a means of identifying the possibilities of introducing new sport-recreational offers with a higher quality of service provision aligned with consumer needs, which would help the Vrućica spa to become more attractive and profitable. Material and methods. After selecting factors of the internal and external environment which influence sport tourism at the spa, the intensity of the impact of each factor was determined through the use of SWOT analysis. Then, by multiplying the average impact of strengths, weaknesses, opportunities, and threats matched in the SWOT Matrix, a polygon SWOT analysis of the strategy was carried out. Conclusion. Having analysed the "Banja Vrućica" spa's environment and having quantified the results, we reached the conclusion that the best solution is to form and implement a WO strategy with regard to sport tourism at the spa, meaning a shift in strategy aimed at keeping the existing activities and structures and developing new products and a new approach to the market.
\end{abstract}

Key words: external and internal environment, management, sport tourism, spa, strategic analysis

\section{Introduction}

Tourism is one of the fastest growing economies in the world [1], which is undergoing continual expansion and diversification in spite of temporary periods of crisis [2]. The number of people travelling abroad for tourism reached 1.135 billion in 2014 , making the total revenue in tourism equal to $\$ 1.245$ billion [3]. As one of the major economies, tourism employs over 100 million people worldwide [4]; in 2015, it had a direct global GDP share of 3\% and an indirect global GDP share of $9.8 \%$ [1]. Diversification and innovation in tourism products have led to the development of selective forms of tourism built around health, nautics, hunting, fishing, gastronomy, entertainment, or event planning [2]. Although all the preconditions and a large potential for the development of tourism exist in Bosnia and Herzegovina, tourism is still in its early stage of development in this country [5].

Spa tourism is one of the oldest types of tourism, originating in antiquity, which has evolved continuously and developed complex and various forms throughout different historical periods, under the influence of political and economic systems, on the one hand, and changes in social options and tourists' interests regarding this type of tourism, on the other [6]. In 2015, there were 121,595 spas that made a revenue of $\$ 77.6$ billion and employed 2.1 million people [7]. Owing to its natural beauties, ecological and climatic diversity, and the vicinity of international markets, the Republic of Srpska in Bosnia and Herzegovina has significant tourism potential, particularly in the category of spa tourism development [8], largely due to its numerous thermal and mineral water springs [9]. In terms of the identified weaknesses of spa tourism in Bosnia and Herzegovina, the main problem is that most of the spas focus on medical treatment only, and they are no different from medical facilities and facilities offering recreational tourism [10]. Of the total investment in spas in the Republic of Srpska, $71.02 \%$ is invested into housing capacities and the hospitality/catering product, $22.86 \%$ is invested into the medical product, and only $6.23 \%$ is allocated to sports and recreation, which is clearly not meeting the demands of the faster development of spa tourism in its sports and recreation category. This percentage investment needs to change in favour of increased investment into the medical and sports and recreation products, as they are the cornerstones of 
the faster development of spa tourism [11]. The "Banja Vrućica" spa has the biggest tourist capacity in Bosnia and Herzegovina, with about 1,000 beds in four hotels and mineral water springs representing the basis of this spa. The healing properties of the thermo-mineral waters of the Vrućica Spa springs were known as far back as the Roman times. The first scientific analysis of the spa waters was carried out at the times of the Austro-Hungarian Empire, while the first accommodation facilities were built at the beginning of the $20^{\text {th }}$ century. The healing properties of the water help in treating cardiovascular, rheumatic, and neurologic diseases. Apart from health tourism, congress tourism is an integral part of the additional tourism offer. The clients are also offered a wide spectrum of sport-recreational activities they can engage in, such as swimming in outdoor and indoor swimming pools, ball games, table-tennis, billiards, and gym exercise, the sport tourism offer being dependent on natural resources. This offer was not always in line with the requirements of a modern tourist, making it difficult for the spa to contribute to the economic growth and development of the national economy and the local community economy, since the guests typically stay for short periods of time. The most important visitors to the spa are congress tourists who typically stay for two days, while the participation of spa tourists is reduced to around 35\% of the total number of visitors who stay significantly longer, unlike congress and sport-recreational tourists.

Sport tourism can be described as a symbiosis of the world's largest social phenomenon and the world's largest economy [12]. This form of tourism includes all kinds of active and passive participation in sport activities which are organised sporadically or regularly for non-commercial or commercial reasons and which require leaving the place of residence or work environment. Even though the origins of sport tourism can be traced back even to ancient times [13], the first connection between sports and tourism appeared in mid-19th century England [14]. In recent decades, sports tourism has gained more importance and has become a topic of interest for researchers [15], but more research is certainly needed in this field. An analysis of individual sectors shows the importance of the increase in sports for the world economy, and the following three sectors stand out: sports tourism, fitness and media, and sports education [16]. Data from 2014 show that sports tourism had a 15\% share ( $\$ 180$ million) in the entire tourism market, whereas the growth of the tourism market in terms of the global GDP was 4-5\% annually, with a $15 \%$ growth rate of sports tourism [3]. Numerous papers on sports tourism have been published since the 1990s, and although, as stated by Ottevanger, these papers were of value and use [17], most of them lacked an adequate evaluation of the findings [18], which is still the case today.

Strategic management is a process which involves analysing the current situation, formulating appropriate strategies, implementing strategies, and providing evaluations, modifications, and alternatives, depending on the needs [19]. The literature, varying from author to author, lists different numbers of basic activities (phases) in the process of strategic management in sports [20, 21, 22, 23, 24]. Based on an analysis of these methods, it is safe to say the process of strategic management can be divided into four basic phases: the analysis of the situation, the formulation of a strategy, the implementation of a strategy, and the evaluation of a strategy. In order to successfully manage a tourist site, it is necessary to formulate long-term goals and decisions [25]. Although the literature does offer sports tourism strategies for entire countries, such as the one described in "Towards a national sports tourism strategy" [26], or for particular regions, e.g. the strategy presented in "Grande Prairie sport tourism strategy" [27], we did not find a single source directly related to the strategic analysis of sports tourism offered by spas in the literature.

This study aims to provide a strategic analysis of sports tourism and propose a strategy to be implemented that would help improve the tourism product offered by the "Banja Vrućica" spa and make it possible for the spa to significantly contribute to economic development in the area. The research was conducted in compliance with ethical standards and the legislation of Bosnia and Herzegovina.

\section{Material and methods}

The analysis of the external environment (External Factors EFAS) is based on a modified PEST analysis [28]. Modifications were made in the selection of the factors of the global environment, which were adjusted to the needs of this study. Two processes - the scanning and monitoring of the environment - were used to provide accurate data on the sports tourism environment of the Republic of Srpska [29]. Having selected the elements of the external environment using the Delphi method, we established that the aforementioned elements represented either opportunities or threats for the strategy of the development of sports tourism at the "Banja Vrućica" spa. Elements representing opportunities were marked with a plus (“+”), and threats were marked with a minus (“-”). The analysis was conducted in four phases. In phase 1 of the analysis, we assessed the impact of a relevant strategic factor on sports tourism at the "Banja Vrućica" spa by means of assigning grades 0 to 5 to factors marked with a "+", depending on their impact on the organisation, and grades -5 to 0 to factors marked with a "-". The " 0 " grade means "no impact", and grade " 5 " implies "crucial impact". Phase 2 involved calculating the average grade of every selected level, based on the impact of individual elements of the environment. Having evaluated the impact of correlated strategic factors on sports tourism at the "Banja Vrućica" spa, in phase 3 , we assessed the importance value of the factors using a grading scale of " 0 " to " 10 " (with " 0 " standing for "no importance" and " 10 " indicating "crucial importance"). This procedure consisted in evaluating the elements of the environment and then calculating average values for every selected dimension. Phase 4 involved producing a chart with the results of the scanning of the environment as well as displaying factor impact, factor relevance, and the sum of opportunities and threats [30].

In the analysis of the internal environment, we made evaluations with the use of the Internal Factor Evaluation (IFE) Matrix [31]. This method produced an evaluation of the main strengths and weaknesses of sports tourism at the "Banja Vrućica" spa and provided a basis for the evaluation of correlation. The IFE Matrix was created in five phases. In the first phase, key internal factors were listed, starting with the strengths and followed by the weaknesses of sports at the Republic of Srpska. The second phase involved assigning weight to each factor, ranging from 0.0 (irrelevant) to 1.0 (fully relevant). The weight added to a factor indicates its importance for sports tourism at the "Banja Vrućica” spa, regardless of whether the particular factor represents a strength or a weakness. The third phase included assigning ratings to each factor, ranging from 1 to 4 . The ratings indicate whether the factor represents a major weakness (grade 1), minor weakness (grade 2), minor strength (grade 3), or major strength (grade 4). The fourth phase involved multiplying the weight of each factor by the rating assigned, which produced the average weight. In the final, fifth phase, the average weight 
values were added up, making it possible to establish an overall weight result for sports tourism at the "Banja Vrućica" spa.

After determining the intensity of the impact of individual factors of the external and internal environment and calculating an average value of the impact intensity of the elements of the SWOT analysis, a matching of the internal and external environment using the TOWS matrix was carried out, and a polygon SWOT analysis of the strategy was produced.

\section{Results}

Table 1 shows the results of the quantitative analysis of the external environment of the "Banja Vrućica" spa in four key PEST areas. The second column indicates whether the selected factor is an opportunity or threat, the third column presents the influence of each factor, column 4 provides information re-

Table 1. Analysis of the factors of the external environment of sports tourism at the "Banja Vrućica" spa

\begin{tabular}{|c|c|c|c|c|}
\hline PEST & $\begin{array}{c}\text { Opportunityl } \\
\text { Threat }\end{array}$ & Factor impact & Factor value & Weight \\
\hline \multicolumn{5}{|c|}{$\mathbf{P}$ (politics, legislation, government) } \\
\hline EE1 & + & 4 & 8 & +32 \\
\hline EE2 & - & 2 & 5 & -10 \\
\hline EE3 & - & 2 & 4 & -8 \\
\hline EE4 & - & 2 & 2 & -4 \\
\hline \multicolumn{5}{|c|}{$\mathbf{E}$ (economy) } \\
\hline EE5 & + & 3 & 5 & +15 \\
\hline EE6 & + & 2 & 4 & +8 \\
\hline EE7 & + & 2 & 6 & +12 \\
\hline EE8 & + & 4 & 8 & +32 \\
\hline EE9 & - & 4 & 6 & -24 \\
\hline EE10 & - & 4 & 5 & -20 \\
\hline \multicolumn{5}{|c|}{ S (society, culture, demographics, environment) } \\
\hline EE11 & + & 3 & 4 & +12 \\
\hline EE12 & + & 2 & 3 & +6 \\
\hline EE13 & + & 2 & 3 & +6 \\
\hline EE14 & + & 3 & 6 & +18 \\
\hline EE15 & + & 2 & 4 & +8 \\
\hline EE16 & + & 2 & 3 & +6 \\
\hline EE17 & - & 4 & 8 & -32 \\
\hline \multicolumn{5}{|c|}{ T (technology) } \\
\hline EE18 & + & 4 & 9 & +36 \\
\hline EE19 & - & 2 & 3 & -6 \\
\hline EE20 & - & 3 & 4 & -12 \\
\hline EE21 & - & 2 & 4 & -8 \\
\hline EE22 & - & 3 & 5 & -15 \\
\hline EE23 & - & 3 & 5 & -15 \\
\hline
\end{tabular}

Legend: EE1 - Law on tourism and strategy of tourism development in the Republic of Srpska; EE2 - Republic of Srpska as an underdeveloped tourist area; EE3 - Poor development of tourism in the Republic of Srpska compared to neighbouring countries; EE4 - Competitiveness of countries in the region; EE5 - Tourism as the third largest global world industry; EE6 - 5\% growth in global revenue from tourism; EE7 - WTO predictions: estimated growth of $4.1 \%$ over a period of 10 years; EE8 - Tourism as an advantage for corporate business in the Republic of Srpska; EE9 - Very small share of tourism in GDP of the Republic of Srpska; EE10 - Modest investments in tourism in the Republic of Srpska; EE11 - Average annual visits; EE12 - Raising health awareness and attractiveness of spa centres; EE13 - Need for active participation in local community life (6E); EE14 - Sudden expansion of tourism in countries where tourism is underdeveloped; EE15 - Pristine environment of the Republic of Srpska; EE16 - Limits of natural resources in smaller areas; EE17 - Small share of tourism in employment figures in the Republic of Srpska; EE18 - Sport activity as an element of modern tourism; EE19 - Domestic tourists as a basis of tourism in the Republic of Srpska; EE20 - Foreign visitors' choice of mountain resorts in the Republic of Srpska; EE21 - Modest tourism development in the Republic of Srpska; EE22 - Incomplete tourism product of the Republic of Srpska; EE23 Mismatch in tourism product of the Republic of Srpska. garding the importance of each factor, and column 5 shows the weight of each factor, which was calculated by multiplying the results in columns 3 and 4, observing the signs from column 2 .

Table 2 shows the average values of the impact and importance of the dimensions of the external environment. The values were calculated with relation to sports tourism at the "Banja Vrućica" spa through the process of adding up the results from Table 1 in columns 3 and 4 and then dividing them by the number of factors, observing the signs from column 2 . Table 2 shows that the biggest importance with regard to making strategic decisions for the spa is given to the economic (5.67), political (4.75), and social (4.43) factors, and the least influence is

Table 2. Average values of the impact and importance of the external environment factors at the "Banja Vrućica" spa

\begin{tabular}{|c|c|c|}
\hline Dimension & Average value of impact & Average value of importance \\
\hline $\mathrm{P}$ & $(+4-2-2-2) / 4=-0.50$ & $(8+5+4+2) / 4=4.75$ \\
\hline $\mathrm{E}$ & $(+3+2+2+4-4-4) / 6=+0.50$ & $(5+4+6+8+6+5) / 6=5.67$ \\
\hline $\mathrm{S}$ & $(+3+2+2+3+2+2-4) / 7=+1.43$ & $(4+3+3+6+4+3+8) / 7=4.43$ \\
\hline $\mathrm{T}$ & $(+4-2-3-2-3-3) / 6=-1.50$ & $(4+2+3+2+3+3) / 6=2.83$ \\
\hline
\end{tabular}

Table 3. Evaluation matrix of the factors of the internal environment of sport tourism at the "Banja Vrućica" spa

\begin{tabular}{|c|c|c|c|}
\hline Internal factors & Value & Grade & Weighted value \\
\hline \multicolumn{3}{|c|}{ S (strengths) } \\
\hline IE1 & 0.03 & 3 & 0.06 \\
IE2 & 0.06 & 4 & 0.24 \\
IE3 & 0.03 & 3 & 0.09 \\
IE4 & 0.04 & 3 & 0.12 \\
IE5 & 0.04 & 4 & 0.16 \\
IE6 & 0.05 & 3 & 0.15 \\
IE7 & 0.08 & 3 & 0.24 \\
IE8 & 0.07 & 3 & 0.21 \\
IE9 & 0.04 & 3 & 0.12 \\
IE10 & 0.05 & 4 & 0.20 \\
IE11 & 0.02 & 3 & 0.06 \\
IE12 & 0.04 & 4 & 0.16 \\
\hline \multicolumn{5}{|c|}{ W (weaknesses) } \\
\hline IE13 & 0.04 & 2 & 0.08 \\
IE14 & 0.10 & 1 & 0.10 \\
IE15 & 0.04 & 2 & 0.08 \\
IE16 & 0.06 & 2 & 0.12 \\
IE17 & 0.03 & 2 & 0.06 \\
IE18 & 0.03 & 2 & 0.06 \\
IE19 & 0.05 & 2 & 0.10 \\
IE20 & 0.03 & 2 & 0.06 \\
IE21 & 0.07 & 1 & 0.07 \\
\hline & 1.00 & \multicolumn{2}{|c|}{1.23} \\
\hline
\end{tabular}

Legend: IE1 - Good geographical location; IE2 - Amount and structure of tourist traffic and housing capabilities; IE3 - Potential of natural environment and its attractiveness; IE4 - Long tradition of spa tourism; IE5 - Competitiveness in pricing; IE6 - Leading position in spa tourism in the Republic of Srpska and Bosnia and Herzegovina; IE7 Experience in the organisation of various events; IE8 - Completed privatisation; IE9 - Renovated and reconstructed housing capacities; IE10 - Various sports programmes in Teslić and in the spa; IE11 - Quality of medicinal and therapeutic programmes; IE12 - Potential of personnel with tourism-related qualifications; IE13 - Illegal construction and harm it inflicts on the spa's specific environment; IE14 - Insufficient investments in sport tourism; IE15 - Lack of orientation to foreign markets; IE16 - Tourists staying below market prices and having low purchasing power; IE17 - Lack of awareness of the spa as a leader in tourism; IE18 - Lack of variety in tourism product (spa viewed primarily as health and medicinal resort); IE19 - Lack of personnel qualified in sport tourism management; IE20 - Low purchasing power of domestic visitors; IE21 - Lack of product for professional athletes. 
Table 4. Intensity of the impact of elements of the SWOT analysis of the "Banja Vrućica" spa

\begin{tabular}{|c|c|c|c|c|c|c|c|}
\hline \multicolumn{8}{|c|}{ Elements of SWOT analysis } \\
\hline $\begin{array}{c}\text { S } \\
\text { (Strengths) }\end{array}$ & Impact intensity & W (Weaknesses) & Impact intensity & O (Opportunities) & Impact intensity & $\mathbf{T}$ (Threats) & Impact intensity \\
\hline $\mathrm{IE} 1$ & 3.00 & IE13 & 4.00 & EE1 & 8.00 & EE2 & 5.00 \\
\hline IE2 & 6.00 & $\mathrm{IE} 14$ & 10.00 & EE5 & 5.00 & EE3 & 4.00 \\
\hline IE3 & 4.00 & IE15 & 4.00 & EE6 & 4.00 & EE4 & 2.00 \\
\hline IE4 & 4.00 & IE16 & 6.00 & EE7 & 6.00 & EE9 & 6.00 \\
\hline IE5 & 4.00 & IE17 & 3.00 & EE8 & 8.00 & EE10 & 5.00 \\
\hline IE6 & 5.00 & IE18 & 3.00 & EE11 & 4.00 & EE17 & 8.00 \\
\hline IE7 & 8.00 & IE19 & 5.00 & EE12 & 3.00 & EE19 & 3.00 \\
\hline IE8 & 7.00 & IE20 & 3.00 & EE13 & 3.00 & EE20 & 4.00 \\
\hline IE9 & 4.00 & IE21 & 7.00 & EE14 & 6.00 & EE21 & 4.00 \\
\hline IE10 & 5.00 & & & EE15 & 4.00 & EE22 & 5.00 \\
\hline IE11 & 2.00 & & & EE16 & 3.00 & EE23 & 5.00 \\
\hline $\mathrm{IE} 12$ & 4.00 & & & EE18 & 9.00 & & \\
\hline Average impact & 4.67 & & 5.00 & & 5.25 & & 4.64 \\
\hline
\end{tabular}

given to the technological factor (2.83). The social and economic factors represent opportunities from the external environment, whereas the technological and political factors represent threats. The economical factor represents a minor opportunity $(+0.50)$, the political one poses a minor threat $(-0.50)$, the social one represents a moderate opportunity $(+1.43)$, and the technological one is a moderate threat $(-1.50)$.

Table 3 represents the evaluation matrix of the factors of the internal environment of the "Banja Vrućica" spa. Column 2 shows the weight of each factor representing a strength or weakness of the internal environment. At the end of the table, it is shown that the total sum of all weights is 1.00 . Column 3 indicates whether the factor represents a major or minor weakness and a major or minor strength, whereas column 4 contains the product of the multiplication of the results shown in columns 2 and 3. The total sum obtained by addition in column 4 is 1.23. According to David and David [31], the total weighted result can vary from low (1.0) to high (4.0), with an average value of 2.5. Total weight values that are far below the average value of 2.5 are characteristic of an organisation whose internal environment is weak, and results well above 2.5 indicate a very strong internal environment. This example shows that the internal environment of sports tourism at the spa is extremely poor.

Table 4 shows the intensity of the impact of the elements of the spa's sports tourism environment. The impact intensity for opportunities and threats is taken from column 4 in Table 1, and that for the strengths and weaknesses is taken from column 2 in Table 3, with the number additionally multiplied by 100 in order to obtain a relative value and to make it comparable to previous data. Average impact is calculated by adding up the intensity of all the selected elements for each part of the SWOT analysis, and then dividing the result by its number, thus giving the average impact for strengths, weaknesses, opportunities, and threats.

Table 5 shows the score from matching the average intensity of the strengths and weaknesses of the internal environment with that of the opportunities and threats of the external environment. Each of the possible pairs of the TOWS matrix is obtained by multiplying the average values in Table 4 .

Figure 1 gives a graphical representation of a polygon SWOT analysis of the strategy, which represents the results obtained in Tables 4 and 5. Figure 1 shows that the best results were ob-
Table 5. Matching of the external and internal environment of the "Banja Vrućica" spa with the SWOT Matrix

\begin{tabular}{|c|c|c|c|}
\hline $\begin{array}{c}\text { SO (maxi-maxi) } \\
\text { Strengths } \mathrm{x} \\
\text { opportunities }\end{array}$ & $\begin{array}{c}\text { ST (maxi-mini) } \\
\text { Strengths } \mathrm{x} \\
\text { threats }\end{array}$ & $\begin{array}{c}\text { WO (mini-maxi) } \\
\text { Weaknesses } \mathrm{x} \\
\text { opportunities }\end{array}$ & $\begin{array}{c}\text { WT (mini-mini) } \\
\text { Weaknesses } \mathrm{x} \\
\text { threats }\end{array}$ \\
\hline 24.52 & 21.67 & 26.25 & 21.25 \\
\hline
\end{tabular}

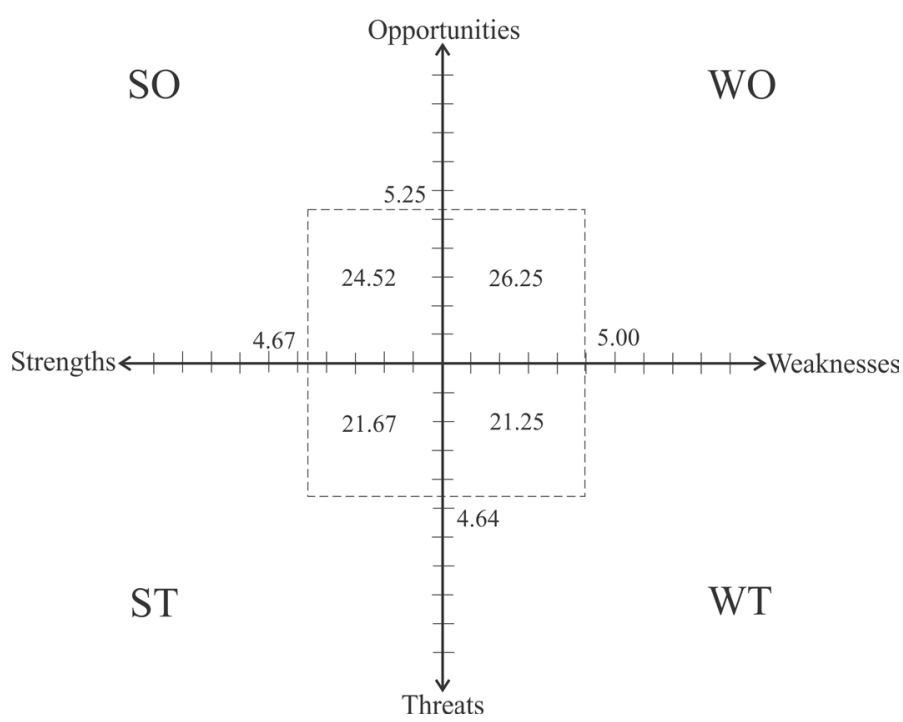

Figure 1. SWOT analysis of the strategy chart

tained in the WO field (26.25), which, according to Koontz and Weihrich [32], means that the "Banja Vrućica" spa has serious weaknesses in sports tourism, despite being in an environment with appropriate opportunities. The strategy needs to be developed in such a way as to neutralise weaknesses and make better use of opportunities. According to the recommendations of Pearce and Robinson [33], in this case, it is necessary to develop a shift strategy; the activity and structure of the organisation should remain the same, but the product and approach to the 
market need to be changed. There is also a possibility to shift the selection of the strategy toward the left WO field (24.52), which means that the organisation has major strengths available, is located in an attractive environment, and needs to develop strengths and exploit the appropriate opportunities of its environment [32]. This further involves the formulation and implementation of an aggressive growth strategy [33] by making routine changes (continuity strategies do not seem executable in this case) through the maintenance of the organisation's activities, structures, and products and changing its approach to the market.

\section{Discussion}

The success of a tourist destination like the "Banja Vrućica" spa can be primarily evaluated by looking at the number of overnight stays. Overnight stays show a constant growth in terms of the number of tourists, but the trend is far below what it should be on the basis of predictions made prior to the armed conflicts in Bosnia and Herzegovina during the 1990s. [34]. This is confirmed by Crnogorac and Babić [35], who point out that the data show a short stay on average from 1996 to 2003, which is a consequence of the change of the structure of the market segments of the spa. The most important visitors to the spa in the aforementioned time frame were seminar/congress tourists who, on average, spend two days in the spa, whereas the visitors visiting the spa made $35 \%$ of the total number of the visitors. These visitors stayed much longer in comparison to seminar visitors or sports and recreational visitors.

Gibson identifies numerous problems related to researching sports tourism. He mentions the lack of connection between policies, research, and education and the need for more multidisciplinary research, especially research based on existing knowledge in sports and tourism [18]. He also states in one of his articles that most research in the field of sports tourism is focused on the type of behaviour of sports tourists, and not on trying to explore the reason why people engage in sports tourism [36]. It can be concluded that, overall, there is ample research covering sports tourism, but particular research documents need clarification. There are only a few research documents that try to give an answer to any "why" question. Instead, they typically only provide general descriptions of sports tourism [17].

When it comes to sports tourism at the "Banja Vrućica" spa, its official webpage has an entire section regarding this type of tourism, divided into three categories: sports fields, fitness, and walking and cycling. However, it is also interesting to examine the section of the webpage which presents the price list. Although the spa's management tried to follow modern trends in tourism and present sports tourism as part of its product, in the document listing prices for services, the services listed are primarily medical and health services. Services related to sports tourism are only mentioned at the very end of the pricelist and are specifically defined here as services related to kinesiotherapy, probably to make a direct connection to the rest of the price list of services connected with medicine and health [37]. This confirms the opinion of Segić [11] that the percentage investment into particular types of services in spa centres needs to change in favour of growth of investment into sports and recreation services as they, aside from medical services, are the bearers of the faster development of spa, medical, and recreational tourism.

In theory, the biggest contribution of the SWOT and TOWS analyses to strategic analysis and the decision-making process is the provision of coherent information on the resources of the organisation and the possibilities arising from them, which can be shown with a matrix and diagram of the strategic position and evaluation of actions in four fields [38]. The polygon of the SWOT analysis of the strategy (Fig. 1) indicates that the strategy which the "Banja Vrućica" spa needs to develop regarding sports tourism is primarily a shift strategy (WO strategy - 26.25). Since there are significant external opportunities and internal weaknesses, the spa should focus on the removal of the weaknesses so that the opportunities may be exploited. Depending on the strategy selected, various types of changes are possible in the organisation, and in this case, a limited changes scenario is needed, where the existing activities and structure should be maintained, and new products (services) along with a new approach to the market are necessary. In the literature, this is known as the strategy of intensive growth, and it "is based on current and potential products (services) and the market of the organisation and efforts and activities to expand the existing market using its own strategic capabilities" [38].

Perhaps there is a possibility of shifting the strategy toward the left, which is the most appropriate situation (SO strategy 24.52) when an organisation with a major strength is faced with environmental factors, suggesting strategies oriented towards growth. This possibility means a continuation of the strategy with routine changes where the existing activity, structure, and product (service) is kept, and a new approach to the market needs to be adopted.

When devising a strategy, it is necessary to take into account limitations in structural changes; thus, a unit or department responsible for sports tourism should be created within the organisational structure of the "Banja Vrućica" spa. Škorić and Bartoluci [39] state that it is very common for hotels to have their sports units or departments. These departments often act as independent profitable centres run by sports managers, and the goals of the departments must be in accordance with the goals of the organisations they are a part of. There is another possibility that needs to be considered - a partnership, where the partners could be numerous sports and sports and recreational organisations, such as clubs in various sports as well as sports and recreational centres offering services related to various sports.

Naturally, it is very important to follow the trends of the very dynamic market of sports recreation when devising a strategic analysis. Some trends identified in sports and recreational tourism include the following: the increased development of individual sports in comparison to team sports, the diversification of the model of participation in sports (people are willing to try a wider range of sport activities), the over-segmentation of sports disciplines, the adaptation of sports activities to the limitations of urban life, and the development of "adventure" mythology in the natural environment [40]. The trend of the development of individual sports is a reflection of social changes in terms of mentality, consisting in heading towards "neoliberalism" and personal development. Participants can gravitate toward other individuals who share their passion for sports, but this is most likely to happen outside of traditional sports events [39]. Surely, this need for individualism in sports will be reflected in tourism activities.

Through his schemes, Rajak [41] tried to present primary impact factors in the selection of destinations for active sports travel. One of the four segments in the schemes is the sports product (service) which creates conditions that are adequate for physical exercise. Therefore, this strategic analysis accentuated the analysis of the existing state of sports facilities and equip- 
ment as well as the procurement of new equipment and new infrastructure.

The limitations of this study primarily relate to the very nature of strategic management, which inherently demands constant evaluation, further requiring continuous monitoring of trends and target groups in the field of sports recreation and sports tourism. Without going deeper into the analysis of this problem, we will point out a new trend in this field: the trend of escapism, that is a sudden and committed sports activation of middle-age people. The trend is present, but it is impossible to tell whether it will be a lasting trend. What is certain is that the reaction needs to be fast and that adequate products and services need to be offered to this target group.

Future analyses of sports tourism at the "Banja Vrućica" spa and the development of strategies need to be concentrated on the opportunities offered by winter sports such as skiing and flyfishing tourism. Crnogorac and Babić [35] pointed out that the mountain slopes are suitable for the construction of ski tracks, and the rivers give an opportunity to offer various tourism products, as well as being appropriate for fishing, which could be an element of the product.

\section{Conclusion}

The percentage investment into particular functions of the "Banja Vrućica" spa needs to change so that investments in medical and sports and recreational products increase, as they are bearers of the faster development of the spa. This would make it possible for the spa to increase its competitiveness in a very demanding market, attract new visitors, and address target groups which have a higher purchasing power, thus opening the possibility of out-of-hotel spending. All of this indicates that sports tourism can make a significant contribution to overall economic development, provided the sports tourism product intended for persons practising recreational and professional sports is properly positioned with respect to the overall quality of the tourism product offered by the "Banja Vrućica" spa and is based on a realistic and well-founded strategy of development.

Our research results have shown that the strategy of sports tourism at the "Banja Vrućica" spa needs to be developed primarily as a shift strategy. Since significant external opportunities exist alongside internal weaknesses, the spa should focus on the removal of weaknesses in order to be able to exploit the opportunities. Thus, limited changes are necessary, meaning that existing activities and structures should be kept, and a new product and approach to the market are needed.

\section{Literature}

1. World Travel and Tourism Council. (2016). Travel and Tourism Economic Impact, 2016, World. London: World Travel and Tourism Council.

2. Bošković T., Mihajlović M. (2016). Contemporary trends in the international tourism market. Škola biznisa 5(1), 121126. DOI: 10.5937/skolbizl-11733. [in Serbian]

3. Yildiz Z., Çekiç S. (2015). Sport tourism and its history and contribution of Olympic Games to touristic promotion. International Journal of Science Culture and Sport 3(3), 326337. DOI: $10.14486 /$ IJSCS394.

4. Kazandzhieva V. (2014). Trends in the development of spa and wellness tourism. In International Tourism Forum "Spa and Wine”, 16-20 October 2014 (pp. 1-8). Sandanski, Bulgaria: Tourism Department of SWU "Neofit Rilski".
5. Arnaut E., Petković D. (2012). Impact of tourism on the macroeconomic stability and economic development of Bosnia and Herzegovina. In The first scientific-expert conference "The development of competent human resources for tourism in the region" (pp. 446-460). Jahorina, Bosnia and Herzegovina: Faculty of Economics, University of East Sarajevo. [in Serbian]

6. Erdeli G., Dincăa A.I., Gheorghilașa A., Surugiu C. (2011). Romanian spa tourism: A communist paradigm in a post-communist era. Human Geographies 5(2), 41-56. DOI: 10.5719/hgeo.2011.52.41.

7. Global Wellness Institute. (2017). Global wellness economy monitor. Miami, FL: Global Wellness Institute ${ }^{\mathrm{TM}}$.

8. Travar D. (2012). Tourism Development Strategy in the Republic of Srpska. Master's thesis, Singidunum University, Belgrade. [in Serbian]

9. Knežević M., Šaula M., Dujaković T. (2014). Importance of health tourism of the Republic of Srpska for tourism development in the region. Poslovne studije 6(11-12), 133-155. [in Serbian]

10. The Foreign Trade Chamber of Bosnia and Herzegovina. (2011). Export strategy for the tourism sector. Retrieved February 7, 2016, from http://www. http://komorabih.ba/ wp-content/uploads/2013/06/bhepa-izvozna-strategijaza-sektora-turizma.pdf. [in Serbian]

11. Segić S. (2011). The development of health spa and recreational tourism in the Republic of Srpska as an opportunity for foreign investors. Časopis za ekonomiju i tržišne komunikacije 1(2), 189-200. [in Serbian]

12. Kurtzman J., Zauhar J. (2005). The emerging profession: Sport tourism management. Journal of Sport Tourism 10(1), 3-14.

13. Zauhar J. (2003). Historical perspectives of sport tourism. In S. Hudson (ed.), Sport and adventure tourism (pp. 2748). Binghampton, NY: Haworth Hospitality Press.

14. Schwark J. (2007). Sport tourism: Introduction and overview. European Journal for Sport and Society 4(2), 117-132.

15. Hodeck A., Hovemann G. (2015). Destination choice in German winter sport tourism: Empirical findings. Polish Journal of Sport and Tourism 22(2), 114-117. DOI: 10.1515/ pjst-2015-0019.

16. Derbăcea-Bolovan M. (2013). Sports tourism, leisure method. Annals of the "Constantin Brâncuși" 5, 103-109.

17. Ottevanger H-J. (2007). Sports tourism: Factors of influence on sport event visit motivation. Master's thesis, Bournemouth University, Dorset.

18. Weed M., Bull C. (2004). Sport tourism: Participants, policy and providers. Burlington, VT: Elsevier Publishing.

19. Coulter M.A. (2013). Strategic management in action. Boston, MA: Pearson.

20. Australian Sports Commission. (2004). Planning in sport: A good practice guide for sporting organizations. Retrieved August 17, 2007, from http://www.ausport.gov.au.

21. Bayle E., Duncan E., Chappelet J-L., Kartakoullis N. (2007). Managing strategically. In J. Camy, L. Robinson (eds), Managing Olympic sport organizations (pp. 61-106). Lausanne, Switzerland: Olympic solidarity.

22. Chelladurai P. (2014). Managing organizations for sport and physical activity: A system perspective. Scottsdale, AZ: Holcomb Hathaway Publishers.

23. Hoye R., Smith A., Nicholson M., Stewart B., Westerbeek H. (2009). Sport management: Principles and applications. Burlington, MA: Elsevier. 
24. Lussier R.N., Kimball D.C. (2014). Applied sport management skills. Champaign, IL: Human Kinetics.

25. Džeko Š., Vukoja B. (2012). Tourism as a factor of the economic development of Bosnia and Herzegovina. In The first scientific-expert conference "The development of competent human resources for tourism in the region" (pp. 546558). Jahorina, Bosnia and Herzegovina: Faculty of Economics, University of East Sarajevo. [in Serbian]

26. Commonwealth Department of Industry, Science and Resources. (2000). Towards a national sports tourism strategy. Retrieved Januray 11, 2016, from http://www. tourism.gov. au.

27. Canadian Sport Tourism Alliance. (2012). Grande Prairie sport tourism strategy. Retrieved Januray 13, 2016, from http://www.gpsportcouncil.ca/wp-content/uploads/2014/ 04/Sport-Tourism-Strategy.pdf.

28. Beech J., Chadwick S. (2013). The business of sport management. London: Pearson Education.

29. Dess G.G., McNamara G., Eisner A.B. (2015). Strategic management: Text and cases. New York: McGraw-Hill Education.

30. Dulčić Ž. (2005). Structure of the environment. In M. Buble (ed.), Strategic management (pp. 17-46). Zagreb, Croatia: Sinergija. [in Croatian]

31. David Fr.R., David Fo.R. (2015). Strategic management: Concept and cases. Upper Saddle River, NJ: Pearson Education, Inc.

32. Koontz H., Weihrich H. (2010). Essentials of management. New Delhi, India: Tata McGraw Hill Education.

33. Pearce J.A., Robinson R.B.Jr. (2015). Strategic management: Formulation, implementation, and control. New York: McGraw Hill.
34. Milinković Z. (2016). Strategic management of the development of the sports and health tourism centre "Banja Vrućica”. Master's thesis, University of Banja Luka, Banja Luka. [in Serbian]

35. Crnogorac Č., Babić V. (2003). Economic aspects of the mountainous tourist area of the Teslić municipality. Turizam 7, 52-54. [in Serbian]

36. Gibson H.J. (2004). Moving beyond the "what is and who" of sport tourism to understanding "why". Journal of Sport Tourism 9(3), 247-265.

37. Banja Vrućica Health Tourism Centre. (2017). Retrieved February 27, 2017, from http://www.banja-vrucica.com. [in Serbian]

38. Sikavica P., Bahtijarević-Šiber F., Pološki Vokić N. (2008). Funadmentals of managment. Zagreb, Croatia: Školska knjiga. [in Croatian]

39. Škorić S., Bartoluci M. (2010). The importance of sports recreation experts in tourism. In 19th Summer School of Croatian Kinesiologists, 22-26 October 2010 (pp. 569-574). Poreč, Croatia: Croatian Kinesiology Association. [in Croatian]

40. Hinch T., Higham J., Sant S-L. (2014). Taking stock of sport tourism research. In A.A. Lew, C.M. Hall, A.M. Williams (eds), The Wiley Blackwell Companion to Tourism (pp. 413424). Oxford: John Wiley \& Sons.

41. Rajak B. (2014). Sport and recreational elements in tourism development, with special emphasis on the territory of Montenegro. Master's thesis, Singidunum University, Belgrade. [in Serbian]

Submitted: March 27, 2017

Accepted: July 21, 2017 